Article

\title{
Investigations on Biogas Recovery from Anaerobic Digestion of Raw Sludge and Its Mixture with Agri-Food Wastes: Application to the Largest Industrial Estate in Oman
}

\author{
Salah Jellali ${ }^{1, *}$, Yassine Charabi ${ }^{1}$, Muhammad Usman ${ }^{1}\left(\mathbb{C}\right.$, Abdullah Al-Badi ${ }^{1,2}{ }^{(-)}$and Mejdi Jeguirim ${ }^{3}(\mathbb{C}$ \\ 1 PEIE Research Chair for the Development of Industrial Estates and Free Zones, Center for Environmental \\ Studies and Research, Sultan Qaboos University, Al-Khoud 123, Muscat, Oman; yassine@squ.edu.om (Y.C.); \\ muhammad.usman@squ.edu.om (M.U.); albadi@squ.edu.om (A.A.-B.) \\ 2 Department of Electrical and Computer Engineering, College of Engineering, Sultan Qaboos University, \\ Al-Khoud 123, Muscat, Oman \\ 3 The Institute of Materials Science of Mulhouse (IS2M), University of Haute Alsace, University of Strasbourg, \\ CNRS, UMR 7361, F-68100 Mulhouse, France; mejdi.jeguirim@uha.fr \\ * Correspondence: s.jellali@squ.edu.om
}

\section{check for}

updates

Citation: Jellali, S.; Charabi, Y.; Usman, M.; Al-Badi, A.; Jeguirim, M. Investigations on Biogas Recovery from Anaerobic Digestion of Raw Sludge and Its Mixture with Agri-Food Wastes: Application to the Largest Industrial Estate in Oman. Sustainability 2021, 13, 3698. https:// doi.org/10.3390/su13073698

Academic Editor: Sara González García

Received: 17 February 2021

Accepted: 19 March 2021

Published: 26 March 2021

Publisher's Note: MDPI stays neutra with regard to jurisdictional claims in published maps and institutional affiliations.

Copyright: (c) 2021 by the authors. Licensee MDPI, Basel, Switzerland. This article is an open access article distributed under the terms and conditions of the Creative Commons Attribution (CC BY) license (https:// creativecommons.org/licenses/by/ $4.0 /)$.

\begin{abstract}
This work is intended to evaluate the technical, environmental, and economic feasibility of converting the sludge produced at an industrial estate's wastewater treatment plant (WWTP) in Oman into energy through anaerobic digestion (AD). In this study, three different scenarios were analyzed. They concerned the digestion of the total amount of the produced sludge alone $\left(240 \mathrm{~m}^{3}\right.$ day $\left.^{-1}\right)$ (scenario 1), and its co-digestion with wet agri-food wastes (AFW) at rates of two tonnes day ${ }^{-1}$ (scenario 2) and ten tonnes day ${ }^{-1}$ (scenario 3). Based on the analyses of sludge samples, an intensive literature review regarding sludge and AFW Physico-chemical and energetic characteristics and the use of the cost-benefit analysis (CBA) approach, it was found that, for the overall duration of the project (20 years), the AD of the sludge alone (scenario 1) permitted the production of $43.9 \mathrm{GWh}$ of electricity, the reduction of greenhouse gas (GHG) emissions (more than 37,000 tonnes equivalent $\mathrm{CO}_{2}\left(\mathrm{TCO}_{2}\right)$ ) and exhibited positive net present value (NPV: \$393,483) and an internal return rate (IRR) of $19.4 \%$. Co-digesting sludge with AFW significantly increased all of these key performance indicators. For instance, scenario 3 results in the recovery of electrical energy of $82.2 \mathrm{GWh}$ and avoids the emission of 70,602 $\mathrm{tCO}_{2}$. Moreover, a higher NPV and IRR of $\$ 851,876$ and $21.8 \%$, respectively, and a payback period (PBP) of only seven years were calculated. The sensitivity analysis revealed that a decrease in total expenses by $15 \%$ results in a significant increase of the NPV and the IRR to $\$ 1,418,704$ and $33.9 \%$, respectively, for scenario 3. Considering a pessimistic assumption (an increase of the total expenses by 15\%), all studied scenarios remain attractive. For instance, for scenario 3 , the NPV, IRR, and PBP were evaluated to $\$ 285,047,13.5 \%$, and 9 years, respectively. Therefore, the co-digestion of sludge with agri-food wastes for energy recovery purposes could be considered a promising, eco-friendly, and economically viable approach in the Omani industrial estates.
\end{abstract}

Keywords: sludge; agri-food wastes; biogas; electricity; greenhouse gas emission; feasibility study

\section{Introduction}

Enormous amounts of sludge are produced worldwide in wastewater treatment plants (WWTP) [1]. These solid wastes could represent a real threat to the environment and human health [2]. Therefore, concerned stakeholders, including public/private organisms, scientists, and civil society, are looking forward to minimize their production [3] and to find out the adapted and sustainable management solutions [1]. These solutions should be technically feasible, economically viable, eco-friendly, and socially acceptable [4]. Various approaches and technologies have been applied to reduce their negative impacts on the environment and/or to convert them into valuable resources. Such technologies mainly 
include dumping in wild/controlled landfills and composting for subsequent use in agriculture, fabrication of building materials, and energy extraction [5-7]. Sludge valorization for energy recovery has emerged as a promising and sustainable approach since it permits converting them into energy (electricity or heat or electricity/heat) that could be used directly in situ for the WWTP's functioning. The principal used technologies for this purpose include combustion, gasification, pyrolysis, and anaerobic digestion (AD) [8-10]. The AD process is a biological process by which the organic compounds contained in a given solid/liquid waste are converted into biogas by using microorganisms. This process involves a series of four biochemical stages including [10,11]: (i) hydrolysis, where complex organic molecules are converted into simple sugars, fatty acids, and peptides; (ii) acidogenesis consisting in the fermentation of the hydrolysis products into short-chain volatile organic acids such as alcohols, butyrate, carbonic acids, and propionates; (iii) acetogenesis where the latter products are converted into acetate, carbon dioxide, and hydrogen; and (iv) methanogenesis where these by-products were converted into methane. Compared to the other technologies, the AD process is highly advantageous due to its lower cost, lower energy consumption, and its ability to produce biogas, which is composed mainly of $60-70 \%$ of methane, $30-40 \%$ of carbon dioxide, and traces of other gases such as $\mathrm{H}_{2} \mathrm{~S}[9,10]$. This biogas can be either cleaned and upgraded to produce bio-methane (that can substitute the natural gas) using water scrubbers [12] or converted into heat or electricity via thermal reactors such as boilers, turbines, and generators $[9,10]$. The generated energy could be used in the WWTP covering a significant proportion of its needs or even sold to the supply grid $[13,14]$. Therefore, through the biogas recovery, the AD installations could represent a concrete opportunity for WWTPs to improve their energy independence. WWTPs can further reduce their operational costs and increase their overall environmental performance by shifting from fossil fuels to renewable energy production and reuse [14].

Anaerobic digestion is being applied as a sustainable way to manage the produced sludge in WWTPs in various countries in the world [14,15]. For instance, in 2019, in China, about $6.8 \%$ of the total produced sludge (2.68 million tonnes (wet basis)) were treated by this technology [15]. They are theoretically generating $132 \mathrm{Mm}^{3}$ of methane and 1.47 million tons of fertilizer [15]. In the Unites States of America (USA), in 2017, about 1240 large-scale WWTPs were equipped with anaerobic digesters [16]. In the European Union (EU), at the end of the last decade, approximately $50 \%$ of the WWTPs were equipped with anaerobic digestion facilities [17]. According to the latest report published in 2020 by the EurObserv'ER barometer which measures the progress made by renewable energies in each of the 28 countries of the EU [18], the overall primary energy production from biogas was estimated to be 16,629.8 Kilotonne of Oil Equivalent (KTOE). The contribution of the sewage sludge was determined to be more than 1593 KTOE (about $9.6 \%$ ). In addition, the gross amount of produced electricity from biogas generated from the AD of biomasses including sludge was estimated to about $62,463 \mathrm{GWh}$. This electricity was mostly produced by Germany, Italy, and United Kingdom with percentages of $52.6 \%$, $13.3 \%$, and $12.1 \%$, respectively.

In addition to the sludge from WWTPs, in industrial estates, large amounts of agrifood wastes (AFW) are produced [19]. These wastes are not appropriately exploited since they are generally dumped in landfills, where they could constitute a serious threat to the environment and human health [19]. Simultaneously, various AFW has higher energetic potential production than sludge due to their more important volatile organic matter contents and degradation rates [20-22]. Indeed, these two parameters' average values are assessed to $90 \%$ and $75 \%$ for AFW [23,24] and only $45 \%$ and $48 \%$ for sludge [10,25], respectively. Therefore, the co-digestion of sludge with AFW has emerged as an interesting way to manage these two kinds of solid wastes [26-28].

Oman has established nine industrial estates in various regions of the country. AlRussayl, in Muscat, is the largest industrial estate in the country. This industrial estate collects and treats all the produced wastewaters in a centralized WWTP. Due to the significant volumes of the generated sludge, its handling in this WWTP represents a substantial 
environmental and social concern. Furthermore, despite their significant energy potential and other valuable resource contents, the whole amount of the produced sludge is dumped into a landfill after its dewatering and drying. This operation might have an important environmental negative impact on water and soil resources and air through the emission of GHG. Thus, this sludge's treatment/valorization (through AD process) could partially resolve these social and environmental issues and offer a relevant economic opportunity to convert it into energy (especially electricity). This generated energy could be injected into the national distribution company grid or directly used in the WWTP to substitute the commercial electricity.

On the other hand, despite the proven efficiency of the AD process for WWTPs' sludge and AFW at both laboratory and field scales, relatively few studies have focused on the technical, environmental, and economic viability of this technology at industrialmoderate-sized WWTPs by using tailored approaches such as the cost-benefit analysis method (CBA). Indeed, CBA has been pointed out among various available economic analytical tools as a well-established method for assessing the projects' viability dealing with solid wastes conversion into energy through AD process [29]. This method allows the determination, versus time, of various cost and benefits indicators essential for facilitating decision-makers' help and orientation. Therefore, this work's main objective is to study the technical, environmental, and economic feasibility of converting the sludge produced at Al-Russayl industrial estate into electricity through the AD process. The economic efficiency of its co-digestion with agri-food wastes produced at the same industrial estate will also be assessed under various options.

\section{Materials and Methods}

\subsection{WWTP of the Al Russayl Industrial Estate}

This study concerns the Al Russayl industrial estate which is the largest one in Oman. It covers $10.8 \mathrm{~km}^{2}$ and contains 334 industries operating in various sectors, including mainly agri-food, steel, aluminum, textile, etc.

According to a 2019 estimation, the average consumed water in this industrial estate is about $4639 \mathrm{~m}^{3}$ day $^{-1}$. The entire wastewater amount generated by this industrial estate is collected and treated by a centralized WWTP. In 2019, the average treated wastewater amount in this WWTP was assessed to be about $2270 \mathrm{~m}^{3}$ day $^{-1}$. The design, main operating parameters, and the flow diagram for wastewater and sludge in this WWTP are given in Figure 1. The wastewater treatment plant is constituted of the following systems: (i) a bar screen chamber that removes objects having size higher than $3 \mathrm{~cm}$ such as plastics, stones, and wood wastes etc.; (ii) a balancing tank with a volume of $420 \mathrm{~m}^{3}$ where the wastewater is collected and homogenized; (iii) a dissolved air flotation unit where the air injection at a flow rate of $200 \mathrm{~m}^{3} \mathrm{~h}^{-1}$ is applied to remove oil and greases; (iv) coagulation-flocculation tanks that permit the removal of suspended and colloidal solids; (v) an anoxic tank, having a volume of $362 \mathrm{~m}^{3}$, that allows the denitrification of wastewater; (vi) a moving bed bioreactor (MBBR) tank with a volume capacity of $796 \mathrm{~m}^{3}$ allowing the removal of the organic pollutants, vii) a clarifier with a volume of $1250 \mathrm{~m}^{3}$ where the wastewaters are separated from the sludge that was created during the biological treatment; viii) a chlorine tank with a volume of $165 \mathrm{~m}^{3}$ that permits the disinfection of the treated wastewaters; and (ix) three parallel tertiary filtration units filled with various materials (from up to bottom: anthracite, activated carbon, fine sand, silex, fine pebbles, and finally coarse pebbles). The discharged wastewater after treatment has a physicochemical-biological quality that permits its reuse for the irrigation of surrounding green spaces. 


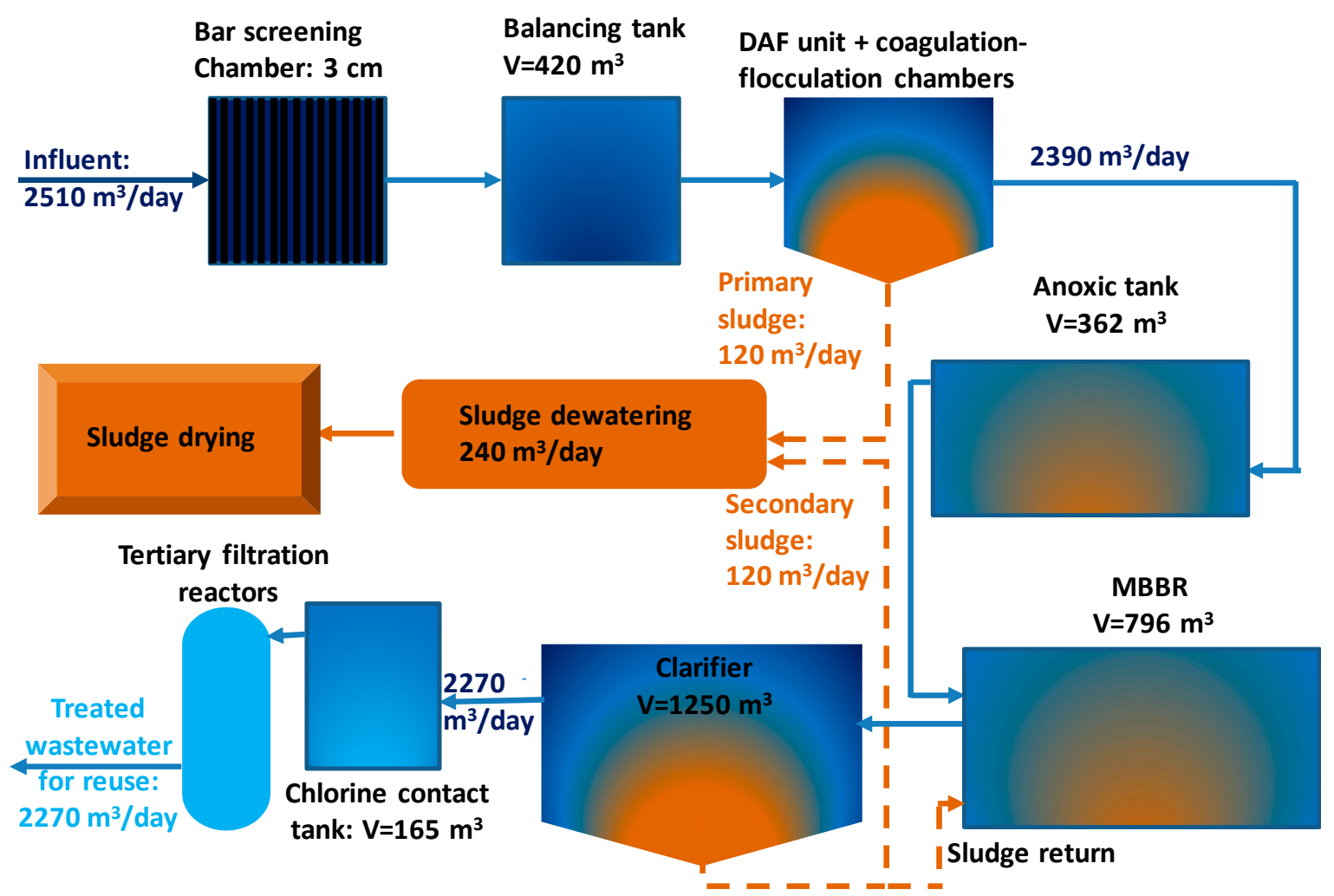

Figure 1. The design and main operating conditions of Al-Russayl wastewater treatment plant. (DAF: dissolved air flotation; MBBR: Moving bed bioreactor).

The total produced sludge amount by this WWTP is $240 \mathrm{~m}^{3} \mathrm{day}^{-1}$ (Figure 1). It is collected from both the coagulation-flocculation and the MBBR biological treatment units at equivalent amounts $\left(120 \mathrm{~m}^{3} \mathrm{day}^{-1}\right.$ for each one). The produced sludge's water content varies between $95 \%$ and $98 \%$, with an average value of $96.5 \%$. This sludge is dewatered in situ by adding various chemicals (like polymers) and centrifugation. The dewatered sludge with a water content of about $75 \%$ is then sun-dried inside the WWTP site and then transferred to landfills for dumping. Therefore, this sludge's adapted management represents an important task to be urgently undertaken to turn them into valuable resources (energy recovery, for instance).

\subsection{Preliminary Characterization of Sludge}

The sludge of Al Russayl industrial estate was subjected to a preliminary characterization including (i) $\mathrm{pH}$ determination for a solid-liquid ratio of 1:5 by a precisely calibrated electrode, (ii) total organic carbon assessment by using the Walkley-Black method, and (iii) the majority of the heavy metals contents were determined through an inductively coupled plasma, mass spectroscopy (ICP-MS) apparatus after a solid-liquid extraction according to the experimental protocol given by Khadhar et al. [30]. A selective electrode quantified fluoride contents.

\subsection{Methods and Data Used for the Feasibility Study}

The technical, environmental, and economic feasibility of the conversion of the produced sludge in the WWTP of Al-Russayl into energy by the AD process was carried out for the following three scenarios:

Scenario 1: The anaerobic digestion of the sludge alone produced in the WWTP;

Scenario 2: The anaerobic co-digestion of the sludge produced in the WWTP mixed with 2 tonnes day ${ }^{-1}$ of agri-food wastes (wet basis); 
Scenario 3: The anaerobic co-digestion of the sludge produced in the WWTP mixed with 10 tonnes day ${ }^{-1}$ of agri-food wastes (wet basis);

Table 1 summarizes the technical, environmental, and economic assumptions and indicators to assess the biogas production and its conversion into electricity in the studied WWTP. All the used parameter values were taken from the literature. Whenever possible, average values given by various studies are calculated and used (Table 1). All the prices given in this manuscript are provided in United States dollars (\$).

Table 1. Main technical, environmental, and economic assumptions and indicators considered for sludge conversion into energy in the WWTP of Al Russayl industrial estate (AFW: Agri-food wastes).

\begin{tabular}{|c|c|c|}
\hline \multicolumn{2}{|l|}{ Biogas Generation } & \multirow{2}{*}{ Reference } \\
\hline Parameter & Value & \\
\hline Project duration (years) & 20 & This study, baseline option \\
\hline Initial raw sludge flow rate $(2021)\left(\mathrm{m}^{3}\right.$ day $\left.^{-1}\right)$-Scenario 1 & 240.0 & Internal report \\
\hline Average solid matter content in raw sludge (\%) & 3.5 & Internal report; $[9,10]$ \\
\hline $\begin{array}{l}\text { Solid dry matter amount in the first year of the project } \\
\text { (tonnes day }{ }^{-1} \text { ) }\end{array}$ & 8.4 & Internal report \\
\hline Annual increase of sludge flow rate (\%) & 2 & This study, baseline option \\
\hline $\begin{array}{l}\text { Average annual dry sludge flow rate }(2021-2040) \\
\left(\mathrm{m}^{3} \text { year }^{-1}\right) \text {-Scenario } 1\end{array}$ & 3724.8 & This study, baseline option \\
\hline Density of thickened sludge $\left(\mathrm{kg} \mathrm{m}^{-3}\right)$ & 1020 & [10] \\
\hline Solid matter content in the thickened sludge $(\%)$ & 25 & [9] \\
\hline Volatile matter (VM) content in sludge (\%) & 45.0 & [10] \\
\hline Volatile matter conversion rate of sludge (\%) & 45.0 & [25] \\
\hline $\mathrm{C} / \mathrm{N}$ ratio range & $6-10$ & [31] \\
\hline Biogas production per $\mathrm{kg}$ of degraded VM of sludge $\left(\mathrm{m}^{3} \mathrm{~kg}^{-1}\right)$ & 1.0 & {$[9,24]$} \\
\hline Initial AFW flow rate (2021) (tonnes day ${ }^{-1}$ ), wet basis-Scenario 2 & 2.0 & This study, baseline option \\
\hline Solid matter content in agri-food wastes (\%) & 20.0 & {$[32,33]$} \\
\hline Initial AFW flow rate (2021) (tonnes day ${ }^{-1}$ ), dry basis-Scenario 2 & 0.4 & \multirow{6}{*}{ This study, baseline option } \\
\hline Annual increase of AFW used flow rate $(\%)$ & 2.0 & \\
\hline $\begin{array}{l}\text { Average annual dry AFW flow rate }(2021-2040) \\
\left(\mathrm{m}^{3} \text { year }^{-1}\right) \text {-Scenario } 2\end{array}$ & 177.4 & \\
\hline Initial AFW flow rate (2021) (tonnes day ${ }^{-1}$ ), wet basis-Scenario 3 & 10.0 & \\
\hline Initial AFW flow rate (2021) (tonnes day ${ }^{-1}$ ), dry basis-Scenario 3 & 2.0 & \\
\hline $\begin{array}{l}\text { Average annual dry AFW flow rate }(2021-2040) \\
\left(\mathrm{m}^{3} \text { year }^{-1}\right) \text {-Scenario } 3\end{array}$ & 886.9 & \\
\hline Volatile matter content in agri food waste (\%) & 90.0 & [33] \\
\hline Volatile matter of AFW conversion rate (\%) & 75.0 & [24] \\
\hline $\mathrm{C} / \mathrm{N}$ ratio range & $11-21$ & [31] \\
\hline Biogas production per $\mathrm{kg}$ of degraded VM of food wastes $\left(\mathrm{m}^{3} \mathrm{~kg}^{-1}\right)$ & 1.1 & {$[24]$} \\
\hline \multicolumn{3}{|l|}{ Electricity generation } \\
\hline Methane content in biogas $(\%)$ & 65.0 & {$[24]$} \\
\hline Lower methane energy content $\left(\mathrm{MJ} \mathrm{m}^{-3}\right)$ & 35.8 & [21] \\
\hline Thermal conversion factor ( $\%)$ & 45.0 & [34] \\
\hline \multicolumn{3}{|l|}{ Gas emission reduction } \\
\hline Electricity Grid emission factor $\left(\mathrm{tCO}_{2} \mathrm{MWh}^{-1}\right)$ & 0.858 & [35] \\
\hline
\end{tabular}


Table 1. Cont

\begin{tabular}{|c|c|c|}
\hline \multicolumn{2}{|l|}{ Biogas Generation } & \multirow{2}{*}{ Reference } \\
\hline Parameter & Value & \\
\hline Sludge transport factor $\left(\mathrm{tCO}_{2}\right.$ per $\left.1000 \mathrm{~km}\right)$ & 0.113 & This study, baseline option \\
\hline Emission reduction benefits rate $\left(\$\right.$ per $\left.\mathrm{tCO}_{2}\right)$ & 2.587 & {$[36]$} \\
\hline \multicolumn{3}{|l|}{ Electricity selling } \\
\hline Omani electricity price for businesses $\left(\$ \mathrm{kWh}^{-1}\right)$ & 0.148 & Internal report \\
\hline Produced electricity from biogas selling price $\left(\$ \mathrm{kWh}^{-1}\right)$ & 0.138 & In this study, the baseline option \\
\hline
\end{tabular}

The project costs include (i) the digester acquisition, (ii) the biogas conversion into electricity $\left(\mathrm{CO}_{2}\right.$ separation step, and electricity generators), and (iii) the operational and maintenance costs:

- The digester price $\left(D_{p}\right)$ was evaluated according to the empirical formula given by Bidart et al. [37]:

$$
D_{p}=18248 * Q_{b}{ }^{0.8586}
$$

where $Q_{b}$ is the produced biogas amount per hour $\left(\mathrm{m}^{3} \mathrm{~h}^{-1}\right)$.

- The average annual cost (investment, operating, and maintenance) of the biogas conversion into electricity through generators was fixed to $\$ 0.07 \mathrm{kWh}^{-1}$ produced. Almost similar values were proposed by Bidart et al. [37] and Morin et al. [38].

- The annual costs related to the digester's operating and maintenance were fixed to $3 \%$ of the capital investment. It is in agreement with the one proposed by Martin [39] and exists in the proposed range by the United States Department of Agriculture (USDA, 2007). This value is higher than the proposed rate suggested by Mohammed et al. [29] when carrying out a feasibility study of biogas integration into Ghana's waste treatment plants (1\%).

The projected incomes of the baseline option are composed of:

- The electricity production revenue (EPR) is equal to the produced amount multiplied by its selling price. This price was fixed to $\$ 0.138 \mathrm{kWh}^{-1}$, which is $\$ 0.01$ lower than the current price by the Omani electricity distribution company $\left(\$ 0.148 \mathrm{kWh}^{-1}\right)$.

- The Certified Emissions Reduction (CER) benefits due to electricity generation from biogas. It is equal to the produced electricity from biogas multiplied by the electricity grid emission factor (EGEF). This factor depends mainly on the used feedstock and technology for electricity production. The EGEF has decreased significantly during the last two decades due to the adoption of cleaner technologies. In 2016, its average value in Europe was estimated to $0.296 \mathrm{tCO}_{2} \mathrm{MWh}^{-1}$. It is only $0.113 \mathrm{tCO}_{2} \mathrm{MWh}^{-1}$ for Finland, $0.440 \mathrm{tCO}_{2} \mathrm{MWh}^{-1}$ for Germany, but reaches $0.812 \mathrm{tCO}_{2} \mathrm{MWh}^{-1}$ for Estonia [40]. For Oman's case, an average value of $0.858 \mathrm{tCO}_{2} \mathrm{MWh}^{-1}$ was proposed by Charabi et al. [35], corresponding to the use of $97 \%$ of natural gas and $3 \%$ of diesel for the production of electricity.

The CER benefits due to the decrease of the sludge amount transfer to landfills. The sludge transport factor was calculated to $0.113 \mathrm{tCO}_{2}$ per $1000 \mathrm{Km}$.

\subsection{Cost-Benefit Analysis}

The cost-benefit analysis (CBA) is a financial method that permits to judge the utility and the profitability of a given project. This judgment is based on the assessment of various parameters such as the net present value (NPV), the internal rate of return (IRR), and the payback period (PBP). 
The NPV is defined as follows [29]:

$$
N P V=\sum_{t=1}^{n} \frac{\left(B_{t}-C_{t}\right)}{(1+r)^{t}}
$$

where $B_{t}$ and $C_{t}$ are the benefits and costs at the year " $t$ ", " $r$ " is the discount or interest rate, and " $t$ " is the year number varying between 1 and 20 .

The IRR refers to the discount rate, making the NVP of the cash flow equal to zero. It is also considered as the average earning power of the project's expenses over the project life [29]. Finally, the Payback period (PBP) is defined as the number of years necessary to recover the investment. Thus, it corresponds to the period where the cumulated benefits cover the cumulated expenses.

\subsection{Sensitivity Analysis}

The sensitivity of the cost-effectiveness of this project was assessed in comparison with the baseline conditions for the following options:

- $\quad$ Option 1: baseline conditions + generated electricity sold at the current price applied by the Omani distribution company: $\$ 0.148$ (7.25\% higher than the one used for the baseline conditions)

- Option 2: Baseline conditions + annual expenses decrease by $15 \%$

- Option 3: Baseline conditions + annual expenses increase by 15\%

\section{Results and Discussions}

\subsection{Preliminary Physico-Chemical Characterization of Sludge}

The sludge physico-chemical characterization shows that it is a slightly acidic media with a $\mathrm{pH}$ of 6.6. Its total organic carbon (TOC) was assessed to $21.0 \%$. As expected, TOC content of this industrial sludge is lower than those observed for those collected from urban WWTPs [41-43]. However, it remains relatively high, permitting the organic matter supply to the micro-organisms to ensure their growth and the biodegradation of the sludge's volatile organic fraction. On the other hand, analyses of the heavy metals showed that except molybdenum, all-metal contents in the sludge were lower than those fixed by the Omani reuse norm in agriculture (Table 2). Molybdenum is most probably discharged in the wastewaters generated by the alloy steel industries operating in this industrial estate. Even if various countries have not yet included molybdenum in the compounds list of their norms [44], it is recommended to remove this component at the producing sources in Al-Russayl industrial estate utilizing mastered technologies as adsorption onto zeolites or activated carbon $[45,46]$. Apart from this component, the calculated ratios between the permissible concentrations fixed by the Omani standards and the measured ones vary between 3.6 and 100. These relatively high ratios suggest that even after the AD process's mass sludge reduction, most of heavy metals contents should remain lower than those fixed by the local reuse norm. It is worth mentioning that the measured sludge heavy metals contents are also lower than the fixed values by the European directive 86/278/EEC [47].

On the other hand, it is essential to underline that a previous analysis of Al-Russayl WWTP's sludge quality [48] have shown that the molybdenum content was about two times lower than the norm $\left(11 \mathrm{mg} \mathrm{kg}^{-1}\right)$. Moreover, this former study showed that only $\mathrm{Cd}$ had contents higher than the Omani fixed norm and the European directive $\left(64.5 \mathrm{mg} \mathrm{kg}^{-1}\right)$. Therefore, it is recommended to carry out further sludge samples analyses to understand heavy metals contents better progress with time. This is an essential aspect to consider if valorization of the digested sludge is planned. 
Table 2. Heavy metals contents in the used sludge in comparison with the standards for sludge reuse in agriculture in Oman (according to 145/93 ministerial decision) and Europe (European directive 86/278/EEC).

\begin{tabular}{|c|c|c|c|c|}
\hline Metal & $\begin{array}{c}\text { Content } \\
\left(\mathrm{mg} \mathrm{kg}^{-1}\right)\end{array}$ & $\begin{array}{c}\text { Omani } \\
\text { Standard }\end{array}$ & $\begin{array}{c}\text { Ratio (Omani } \\
\text { Stan- } \\
\text { dard/Measured } \\
\text { Content) }\end{array}$ & $\begin{array}{l}\text { European } \\
\text { Standard }\end{array}$ \\
\hline Arsenic & $<4$ & - & - & - \\
\hline Boron & 20 & - & - & - \\
\hline Barium & 49 & - & - & - \\
\hline Cadmium & $<4$ & 20 & - & $20-40$ \\
\hline Cobalt & 2 & - & - & - \\
\hline Chromium & 190 & 1000 & 5.3 & - \\
\hline Copper & 280 & 1000 & 3.6 & $1000-1750$ \\
\hline Mercury & 0.1 & 10 & 100 & $16-25$ \\
\hline Manganese & 210 & - & - & - \\
\hline Molybdenum & 36 & 20 & 0.6 & - \\
\hline Nickel & 29 & 300 & 10.3 & $300-400$ \\
\hline Lead & 90 & 1000 & 11.1 & $750-1200$ \\
\hline Antimony & $<7$ & - & - & - \\
\hline Selenium & $<2$ & 50 & - & - \\
\hline Vanadium & 12 & - & - & - \\
\hline Zinc & 270 & 3000 & 11.1 & $2500-4000$ \\
\hline Total cyanide & $<0.5$ & - & - & - \\
\hline Fluorides & $<500$ & - & - & - \\
\hline
\end{tabular}

It is important to underline that high contents of heavy metals in feedstocks could negatively impact the development of methanogens bacteria during the AD process $[49,50]$. Therefore, the co-digestion of this industrial sludge with AFW would potentially contribute to the dilution of heavy metals contents and consequently to improve the blended biomass (sludge and AFW) conversion into biogas.

\subsection{Biogas and Electricity Production Capacities}

The produced sludge and agri-food wastes in generating biogas, methane, and electricity were calculated based on the assumptions presented in Table 1 for the three selected scenarios (see Section 2.5). Owing to the dry and hot climate of Oman, these wastes are expected to be anaerobically digested under mesophilic conditions (temperature between 30 and $\left.38{ }^{\circ} \mathrm{C}\right)$ and for an average residence time of 20 days [9]. Indeed, low residence times ( $<10$ days) do not allow optimal bacterial growth [11]. Whilst, increasing residence times over 20 days will not permit a significant improvement in volatile matter degradation and biogas production [10,51]. Moreover, the use of higher residence time is generally accompanied by higher capital cost (larger size of digester), and requires more energy for process operation such as sludge mixing [9]. Obtained results (Table 3) showed that the AD of the Al Russayl WWTP sludge alone (scenario 1) has a significant potential for biogas recovery. Indeed, the average annual amounts of biogas and methane were estimated to be more than 0.75 and 0.49 Million $\mathrm{m}^{3}$ year $^{-1}\left(\mathrm{Mm}^{3}\right.$ year $\left.{ }^{-1}\right)$, respectively. As indicated above, the produced methane amount depends on the quantity and characteristics of the used sludge and the temperature and hydraulic residence time [10,14]. For that reason, large amounts of methane are produced in bigger WWTPs. For instance, in the Ankara WWTP, the 
biggest one in Turkey, designed for a daily flow rate of $0.971 \mathrm{Mm}^{3}$ day ${ }^{-1}$ produced through eight anaerobic digesters, a total methane amount than $11.8 \mathrm{Mm}^{3}$ year ${ }^{-1}$ [52]. During the entire project's lifetime, the biogas and methane amounts from the $\mathrm{AD}$ of the sludge alone were assessed to about 15.1 and $9.8 \mathrm{Mm}^{3}$, respectively (Table 3 and Figure 2). This biogas permits producing a total electricity amount of about 43.9 GWh during the 20 years' project duration. The average annual produced electricity corresponds to about $2.2 \mathrm{GWh}$. This production is about $34.4 \%$ higher than the total consumed electricity amount by the WWTP in 2020. It is about $13.5 \%$ higher than the average consumed amount in the two previous years that were not affected by the Corona virus pandemic. This calculated generated electricity by Al-Russayl sludge is higher than the one produced in the Rovereto WWTP, Italy $\left(1.4 \mathrm{GWh}\right.$ year $\left.{ }^{-1}\right)$, which treats a lower sludge flow rate $\left(90 \mathrm{~m}^{3}\right.$ day $\left.^{-1}\right)$. It is lower than those produced in big plants such as those of Ankara, Turkey; Budapest, Hungary, and Philadelphia, the USA, which are producing $25.5,38.8$, and $49.1 \mathrm{GWh}^{-1} \mathrm{ar}^{-1}$ and satisfying about $90 \%$ [52], 65\% [53], and 54\% [54] of these plants electricity needs, respectively.

Table 3. Annual and project lifetime (20 years) biogas, methane, and electricity produced amounts from the digestion of Al Russayl WWTP sludge or its co-digestion with agri-food wastes (Scenario 1: SS alone; Scenario 2: SS+ 2 tonnes day ${ }^{-1}$ of AFW; Scenario 3: SS+ 10 tonnes day ${ }^{-1}$ of AFW).

\begin{tabular}{|c|c|c|c|}
\hline & Scenario 1 & Scenario 2 & Scenario 3 \\
\hline $\begin{array}{l}\text { Average annual produced biogas } \\
\left(\mathrm{Mm}^{3} \text { year }^{-1}\right)\end{array}$ & 0.754 & 0.886 & 1.413 \\
\hline $\begin{array}{l}\text { Total biogas amount during the project } \\
\text { lifetime }\left(\mathrm{Mm}^{3}\right)\end{array}$ & 15.085 & 17.719 & 28.255 \\
\hline $\begin{array}{l}\text { Average annual produced methane } \\
\qquad\left(\mathrm{Mm}^{3} \text { year }^{-1}\right)\end{array}$ & 0.490 & 0.576 & 0.918 \\
\hline $\begin{array}{l}\text { Total methane produced amount } \\
\text { during the project lifetime }\left(\mathrm{Mm}^{3}\right)\end{array}$ & 9.806 & 11.518 & 18.366 \\
\hline $\begin{array}{l}\text { Average annual produced electricity } \\
\left(\text { GWh year }{ }^{-1}\right)\end{array}$ & 2.195 & 2.578 & 4.111 \\
\hline $\begin{array}{l}\text { Total produced electricity during the } \\
\text { project lifetime (GWh) }\end{array}$ & 43.892 & 51.555 & 82.210 \\
\hline
\end{tabular}

It is essential to underline that Oman has to carry out massive efforts related to sludge conversion into electricity in Al-Russayl industrial estate and other urban WWTPs producing substantial amounts. This will permit Oman to go in the same direction as some European developed countries who are producing large energy amounts from the AD of sludge only, such as Germany, UK, the Netherlands, and Sweden [55].

Owing to their higher organic matter contents and anaerobic biodegradability (see Table 1), co-digesting sludge with agri-food wastes has significantly increased the produced biogas, methane, and electricity amounts (Table 3). An increase in agri-food wastes flow rate improves biogas, methane, and electricity production (Figure 2). For instance, when the sludge was mixed with 2 and 10 tonnes day ${ }^{-1}$ of agri-food wastes, the produced electricity increased from $43.9 \mathrm{GWh}$ by about $17.5 \%$ and $87.3 \%$ to reach 51.6 and $82.2 \mathrm{GWh}$, respectively. This is mainly because the agri-food wastes' volatile matter contents, $\mathrm{C} / \mathrm{N}$ ratio, and degradability capacities are much higher than those of the Al-Russayl WWTP's sludge. Indeed, the AFW' volatile matter contents and $\mathrm{C} / \mathrm{N}$ of agri-food wastes are about two times higher than that of the sludge [31]. 


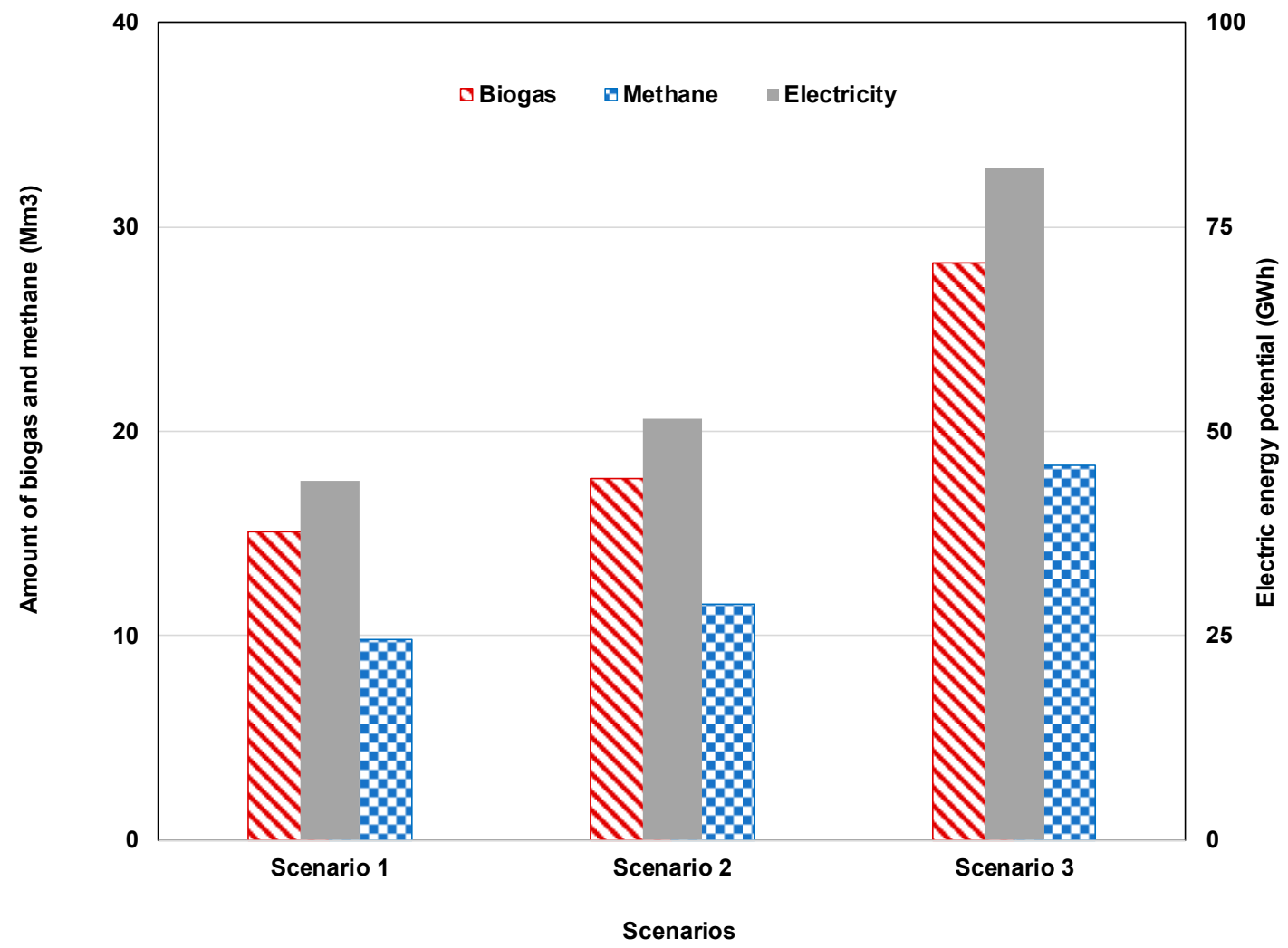

Figure 2. Biogas, methane, and electricity generation capacities during the lifetime project by the digestion of sewage sludge alone (SS) and its co-digestion with agri-food wastes (AFW) (Scenario 1: SS alone; Scenario 2: SS+ 2 tonnes day $^{-1}$ of AFW; $^{\circ}$ Scenario 3: SS+ 10 tonnes day ${ }^{-1}$ of AFW).

Similar trends were reported by both laboratory and field studies. For instance, at a laboratory scale, Keucken et al. [26] reported an increase of methane production by $20-40 \%$ when co-digesting sludge with organic food wastes at a ratio of 1:1 (based on the volatile matter contents). In addition, Mattioli et al. [56] studied the co-digestion of the sludge produced in Rovereto WWTP (Italy) at a flow rate of $90 \mathrm{~m}^{3}$ day $^{-1}$ and a solid content percentage of $4.3 \%$, with 10 tonnes day ${ }^{-1}$ of municipal organic wastes. They reported an increase of the annual biogas production from about 0.482 to $0.993 \mathrm{Mm}^{3}$, doubling the amount of generated power from about 1.4 to $2.8 \mathrm{GWh}_{\text {year }}{ }^{-1}$. This enabled the plant to recover about $85 \%$ of its total energy demand. Furthermore, Koch et al. [57] studied the digestion of sludge generated from the WWTP of Garching/Alz, Germany, and its co-digestion with $10 \%$ of food wastes within a $1350 \mathrm{~m}^{3}$ digester volume. They showed that the annual methane produced amount increased from $85,494 \mathrm{~m}^{3}$ year ${ }^{-1}$ to more than $163,000 \mathrm{~m}^{3}$ year ${ }^{-1}$. This has increased the self-generated energy from $25 \%$ to $78 \%$. They imputed this better energy performance during the co-digestion process to the higher $\mathrm{C} / \mathrm{N}$ ratio of the used food waste (17.7) than the raw sludge (8.8). Finally, Maktabifard et al. [58], based on a comparative study on 176 WWTPs in Germany, reported that about $44 \%$ of these plants could achieve energy neutrality through sludge co-digestion with other organic substrates.

It is worth mentioning that the co-digestion of sludge with an important fraction of AFW could, under certain conditions, negatively impact the AD process due to the excessive presence of $\mathrm{Na}^{+}$and free-ammonia-nitrogen [31]. These two components could interfere with the metabolic process of the microbial activity and lead to the accumulation of volatile fatty acids, respectively [31]. Koch et al. [59] studied the co-digestion of raw sludge and food waste using different mass-based mixtures in batch trials. They showed that sludge co-digestion with food wastes fractions, up to $12.5 \%$ (mass-based) or $35 \%$ (volatile solids based), significantly improved the methane yields and kinetic production. 
In our case, the AFW fraction is relatively low ( $0.7 \%$ for scenario 1 and $3.4 \%$ for scenario 2$)$ which is expected not to negatively influence the AD process.

Figure 3 summarizes the annual flow diagram of the sludge and sludge mixed with AFW conversion into energy. It has been found that higher is the AFW amount, more important is the produced electricity. Moreover, significant reduction in the amounts of sludge and AFW after the AD process is also clear. The produced digestate is generally rich in nutrients and could be valorized in agriculture as a biofertilizer. However, before that, an in-depth physico-chemical characterization (especially its heavy metals and nutrients contents) is necessary to ensure its safe and optimal reuse.

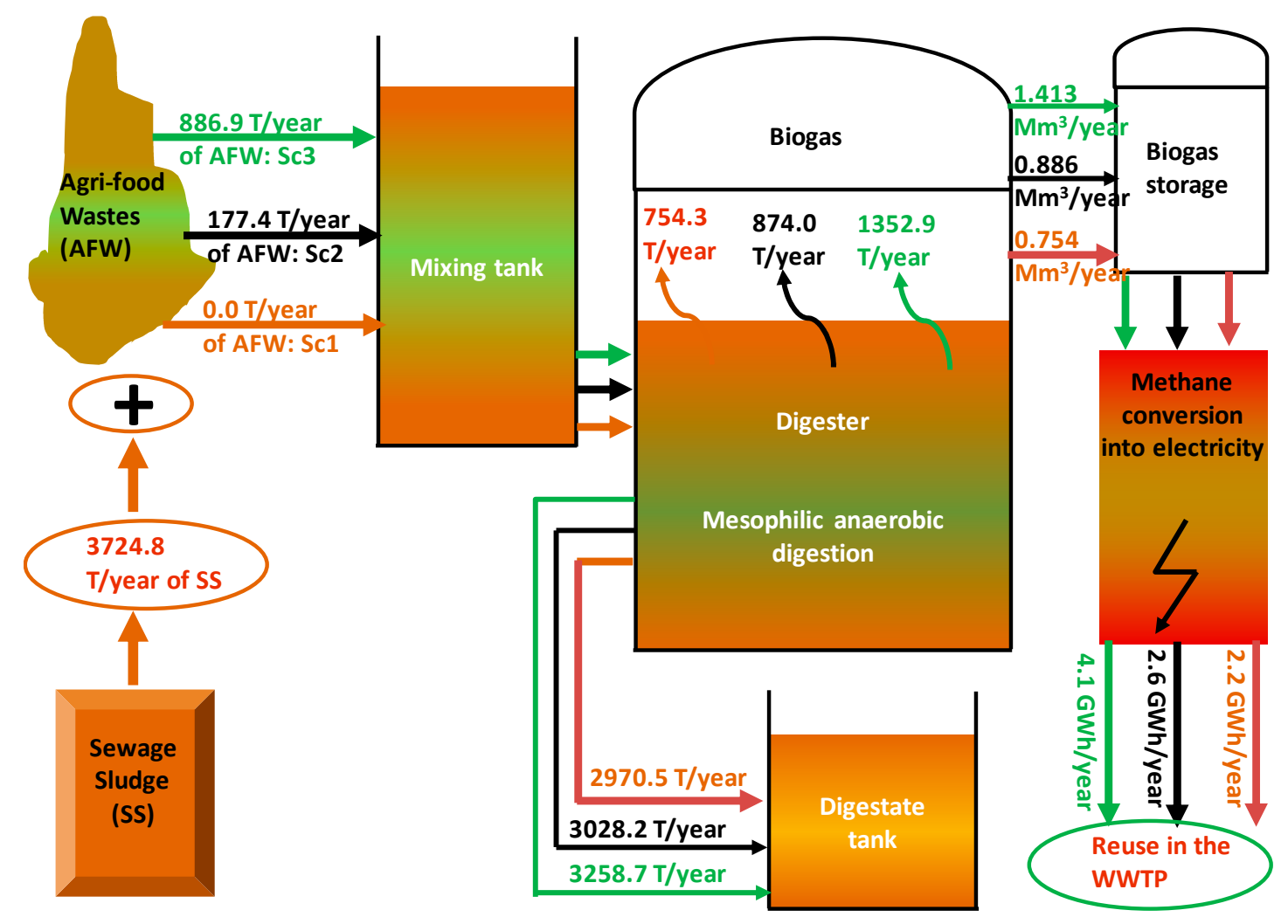

Figure 3. Average annual flow diagram of the conversion of sludge and AFW into energy (WWTP: wastewater treatment plant; Sc: Scenario where Sc1: SS alone; Sc2: SS+ 2 tonnes day ${ }^{-1}$ of AFW; Sc3: SS+ 10 tonnes day ${ }^{-1}$ of AFW).

\subsection{Emissions Reduction Potential}

According to the Intergovernmental Panel on Climate Change (IPPC), WWTPs contribute to the GHG emissions in the atmosphere during the wastewaters and sludge treatment and management [60]. The carbon footprint represents the direct or indirect emissions of total emissions of $\mathrm{CH}_{4}$ and nitrous oxide $\left(\mathrm{N}_{2} \mathrm{O}\right)$ caused directly or indirectly by the WWTP. The direct GHG emissions are originated from biological processes during: (i) wastewaters collection, (ii) wastewaters treatment, and (iii) wastewaters discharge [61]. Inside the Al-Russayl WTTP, the direct $\mathrm{N}_{2} \mathrm{O}$ emission could probably occur at three locations based on literature [61,62]: the anoxic tank, the MBBR unit and in the receiving water body. However, the $\mathrm{CH}_{4}$ emission should occur mainly in the DAF and coagulationflocculation unit, in the sludge dewatering step, in the sludge drying basin, and in the receiving water body [61]. The indirect GHG emissions in WWTPs mainly include those related to the electricity supply and the sludge transportation to the landfill.

In our case, the carbon footprint due to direct emissions of GHG emissions of the Al-Russayl WWTP cannot be precisely estimated due to the availability of limited data concerning the wastewater quality progress in the treatment line. However, based on the 
literature, the direct $\mathrm{N}_{2} \mathrm{O}$ emission in the WWTPs could vary in a large range between $0.003 \%$ and $0.6 \%\left(\mathrm{Kg} \mathrm{NO}_{2}-\mathrm{N} / \mathrm{Kg}\right.$ total $\left.\mathrm{N}(\mathrm{TN})\right)$ depending on the wastewaters loads and operating conditions [61,63]. Concerning the $\mathrm{N}_{2} \mathrm{O}$ emission in the water receiving body, it is generally fixed to $0.5 \%$ of the effluent TN content [60]. Regarding $\mathrm{CH}_{4}$ emission, it is usually more complicated to be evaluated in comparison to $\mathrm{NO}_{2}$. However, for the whole WWTP, it is generally up to $30 \%$ of the produced biogas [64]. In the receiving water bodies, the $\mathrm{CH}_{4}$ emission is equal to $0.025 \mathrm{~kg} \mathrm{CH}_{4} / \mathrm{kg}$ of chemical oxygen demand (COD) of the effluent [60]. Regarding the sludge line, the $\mathrm{CH}_{4}$ is emitted during: the storage and dewatering of the digested sludge and the heat and electricity production unit (non-burned methane) at percentages of $2-4.5 \%$, and $1.3-1.8 \%$ of the total produced $\mathrm{CH}_{4}$ amount [61]. In the current study, we focused mainly on the avoided indirect GHG emissions $\left(\mathrm{CO}_{2}\right.$ equivalent amount) due to the $\mathrm{AD}$ of the sludge alone and mixed with AFW (Figure 3). Therefore, two indirect aspects have been considered: (i) the substitution of the used electricity from the national grid by the one produced from biogas, and (ii) the reduction of the sludge amount to be transported from Al-Russayl WWTP to the landfill by trucks. For a grid electricity emission factor of $0.858 \mathrm{tCO}_{2} \mathrm{MWh}^{-1}$ [35], the emissions avoidance potential per year and during the project lifetime by the electricity generation from Al-Russayl WWTP sludge only (scenario 1) was estimated to be about 1883 and $37,659 \mathrm{tCO}_{2}$, respectively. The average annual and "total" reduced GHG emission reached about 2212; "44,235" and 3527; and "70,536" $\mathrm{tCO}_{2}$ year ${ }^{-1}$ when the sludge was co-digested with 2.0 (scenario 2) and 10.0 (scenario 3) tonnes day ${ }^{-1}$ of AFW, respectively (Figure 4). The avoided GHG emissions due to fuel combustion during the sludge transportation to landfills were calculated for transporting trucks capacities of seven tonnes, a distance from the WWTP to the landfill of $50 \mathrm{~km}$ and a sludge transport factor of $0.113 \mathrm{kgCO}_{2} \mathrm{~km}^{-1}$. They were estimated to only $66 \mathrm{tCO}_{2}$ year ${ }^{-1}$ for the three studied scenarios. This value is very low compared to those calculated when using the electricity generated by the biogas instead of the national grid. It is worth mentioning that the total GHG emission avoidance in the case of the WWTP of Al-Russayl remain relatively low compared to those calculated for larger WWTPs. For example, in South Columbus, USA, a net GHG emission reduction of $9600 \mathrm{tCO}_{2}$ year $^{-1}$ is achieved through the co-digestion of sludge with fat, oils, grease, and co-generation heat and power [14].

In Oman's case, it is essential to underline that stringent emission reduction policies and appropriate incentives for bioenergy can encourage the further adoption of biogas recovery from sludge and other organic-matter-rich-materials [65]. For instance, the European Union uses the "renewable energy directive (2018/2001/EU)" as an efficient framework for member countries to achieve $\mathrm{CO}_{2}$ emission reduction targets. Bioenergy from anaerobic digestion of organic wastes (including sludge) is stimulated within this framework for further emissions reduction potential and environmental preservation [65]. 


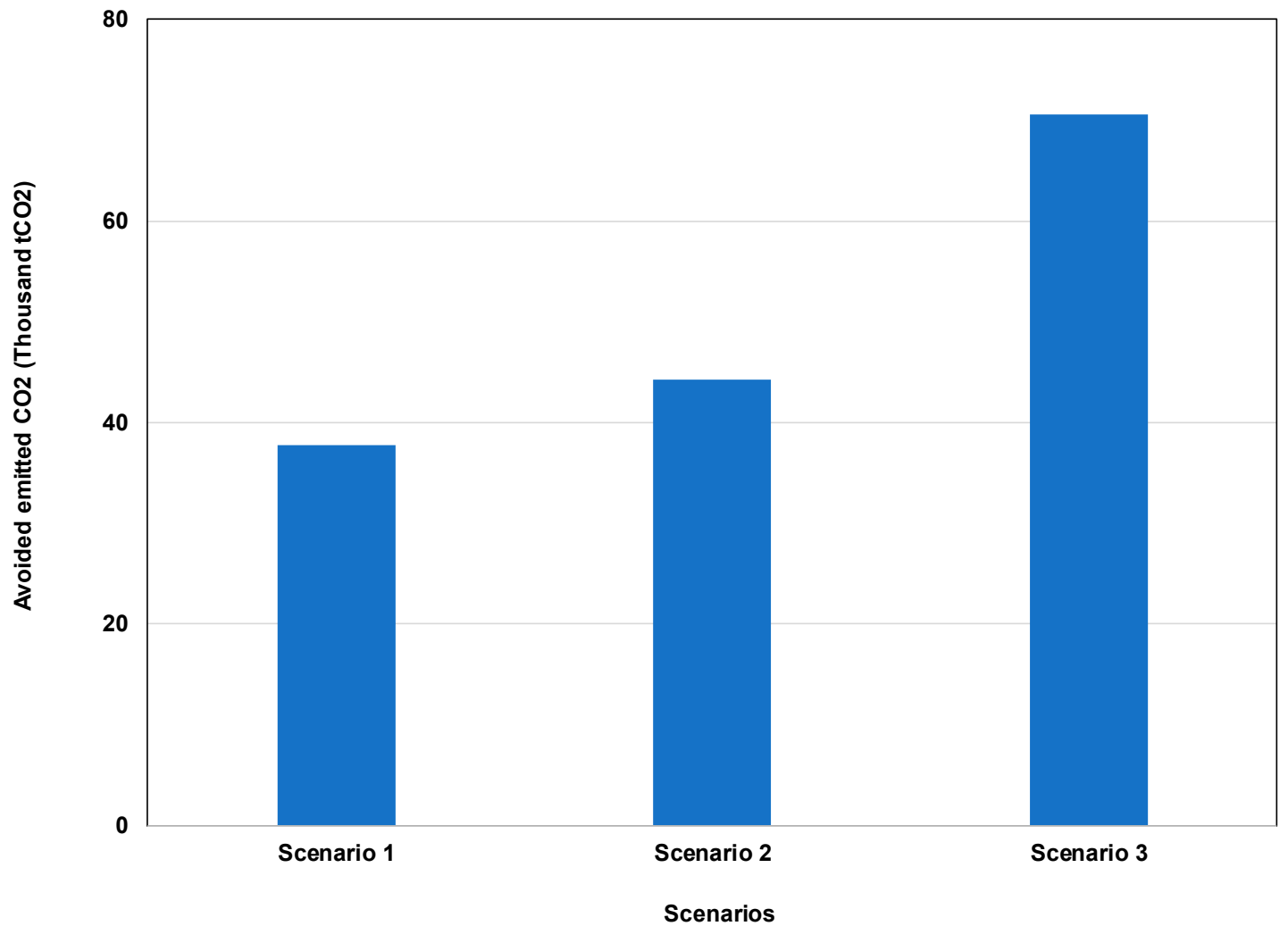

Figure 4. $\mathrm{CO}_{2}$ emission reduction potential during the lifetime of project by the digestion of sewage sludge (SS) alone and its co-digestion with agri-food wastes (AFW) (Scenario 1: SS alone; Scenario 2: SS+ 2 tonnes day ${ }^{-1}$ of AFW; Scenario 3: SS+ 10 tonnes day ${ }^{-1}$ of AFW).

\subsection{Economic Performance}

The total digester cost and related operating and maintenance costs for the anaerobic digestion of the produced sludge in the studied WWTP were found to be $\$ 1.082$ million by using Equation (1). This cost increases to about $\$ 1.242$ and $\$ 1.855$ million for scenarios 2 and 3, respectively. On the other hand, the total electricity generation cost from methane was determined to be about $\$ 3.235, \$ 3.800$, and $\$ 6.060$ million for scenarios 1,2 , and 3, respectively. It can be deduced that the cost of biogas conversion into energy is much higher than the one related to the digester implementation, operating, and maintenance cost.

Regarding the revenue of this project, it is mainly constituted by the generated electricity selling. The other items, such as the CER benefits from the avoided GHG emissions and transport fuels, were relatively low. For instance, for scenario 2 and 3 , the selling benefits of produced electricity was evaluated to $\$ 7.115$ and $\$ 11.345$ million and counted for about $98.1 \%$ and $98.2 \%$ of the total benefits, respectively.

Considering the economic feasibility of the produced sludge and AFW in the industrial estate conversion into electricity, it can be seen from Figure 5 that the three studied scenarios were financially feasible as their calculated NPV values over the project lifetime were positive. For scenario 1 (biogas recovery from sludge alone), the NPV is estimated to $\$ 393,483$ over the project lifetime with an IRR and PBP of $19.4 \%$ and seven years, respectively. The most excellent feasibility is offered by the biogas recovery from the co-digestion of the sludge and 10 tonnes day ${ }^{-1}$ of agri-food wastes (Scenario 3), where the NPV, the IRR, and PBP were assessed to be $\$ 851,876 ; 21.8 \%$ and six years, respectively (Figure 5 and Table 3). 




Figure 5. Calculated net present value (NPV) and internal return rate (IRR) of the Al-Russayl WWTP sewage sludge (SS) digestion or co-digestion with agri-food wastes (AFW) project for the baseline conditions (Scenario 1: SS alone; Scenario 2: SS+ 2 tonnes day ${ }^{-1}$ of AFW; Scenario 3: SS+ 10 tonnes day $^{-1}$ of AFW).

It is essential to underline that it is complicated to compare these values to those found in the literature. Indeed, such operation's efficiency depends on the feedstock's nature and flow rate, the $\mathrm{AD}$ process conditions (primarily temperature and residence time), the size of the used digesters, and the efficiency of the methane conversion into electricity $[14,29,66]$.

\subsection{Sensitivity Analysis Results}

Since this economic study was performed under particular assumptions, it is important to carry out a sensitivity analysis that considers market instability versus time and costs vary. The studied options (see Section 2.4) showed that all of them were economically feasible. Indeed, the corresponding NPV and IRR were positive and higher than 10\%, respectively (Figure 6a,b and Table 4). Option 1, which assumes that the generated electricity will be sold to businesses at the same price currently applied by the Omani electricity distribution company (0.148 \$US $\mathrm{kWh}^{-1}$ ) instead of $0.138 \$ \mathrm{US} \mathrm{kWh}^{-1}$ (baseline simulation), has significantly increased the NPV and IRR for all the studied scenarios. Indeed, the related calculated NPV and "IRR" reached \$0.552, \$0.667, and \$1.148 million and “23.1\%", “23.8\%", and "26.0\%" for scenario 1, 2, and 3, respectively (Table 3 and Figure 6a,b). 

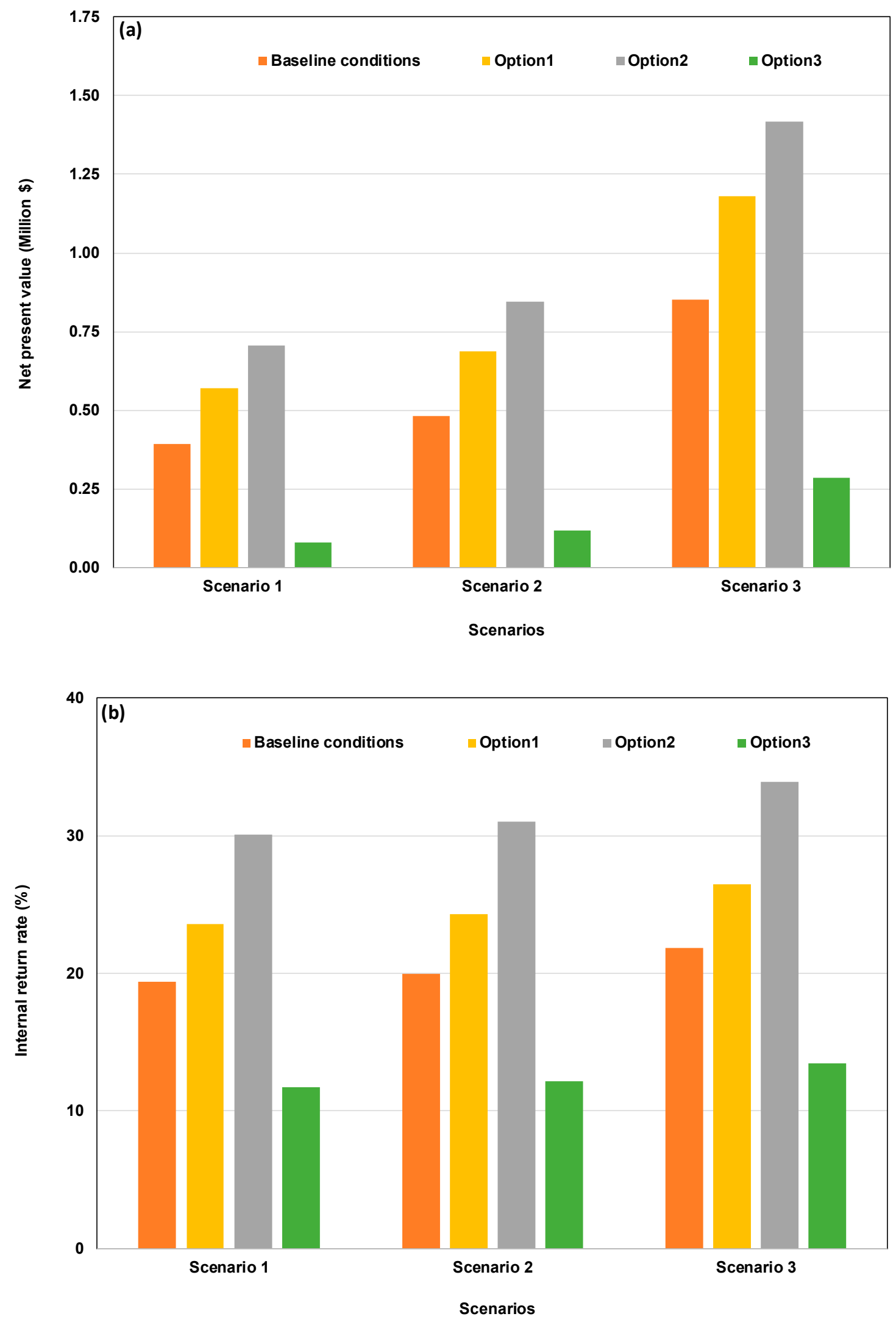

Figure 6. Cont. 


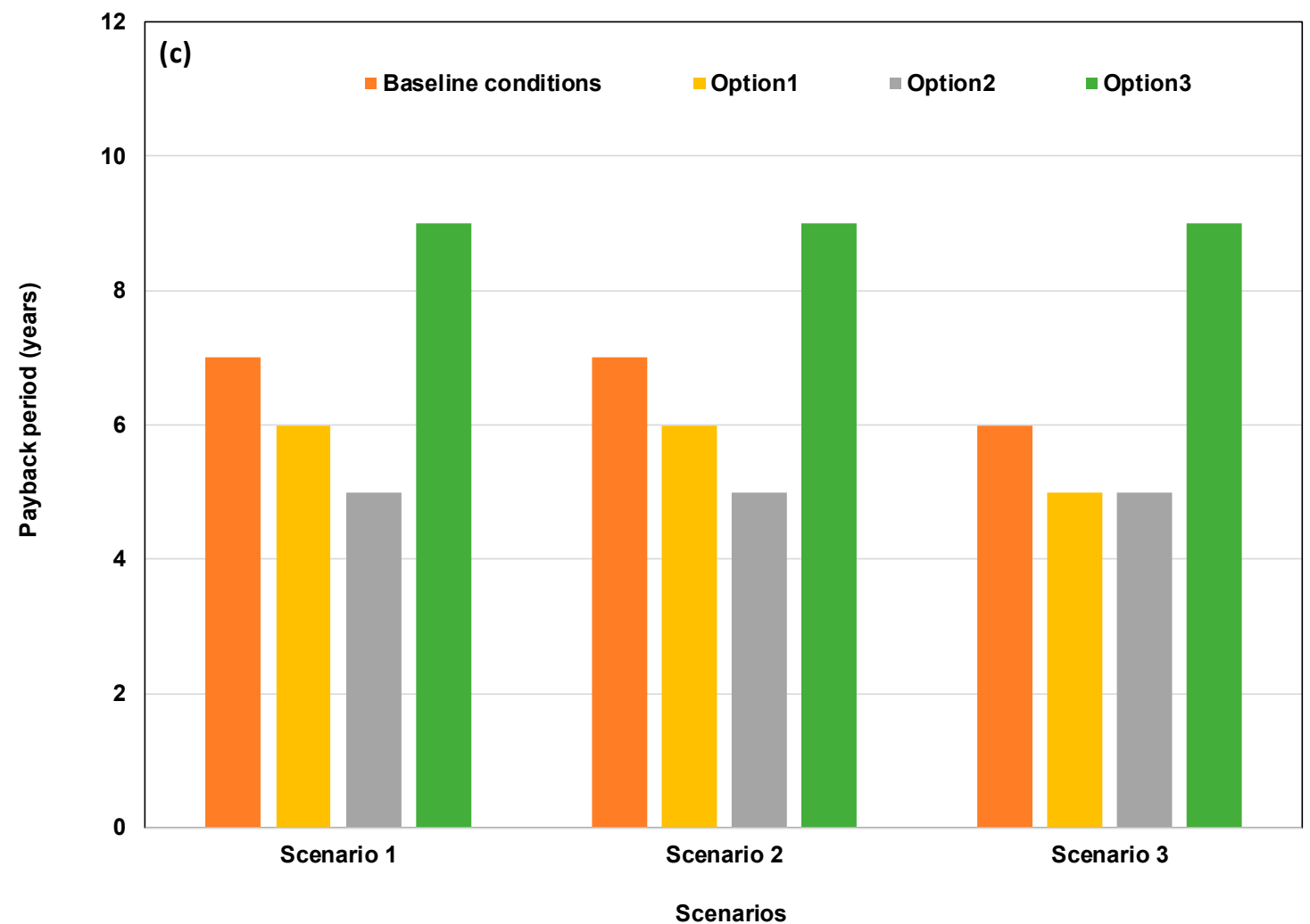

Figure 6. Economic feasibility of electricity production from Al-Russayl WWTP sludge and agri-food wastes co-digestion process. Sensitivity study effects on Net present value (a), Internal return rate (b), and Payback period (c) (Scenario 1: SS alone; Scenario 2: SS+ 2 tonnes day ${ }^{-1}$ of AFW; Scenario 3: SS+ 10 tonnes day ${ }^{-1}$ of AFW; Baseline conditions: electricity selling price $=\$ 0.138 \mathrm{kwh}^{-1}$; Option 1: electricity selling price $=\$ 0.148 \mathrm{kwh}^{-1}$; Option 2: baseline conditions + annual expenses decrease by $15 \%$; Option 3: Baseline + annual expenses increase by $15 \%$ ).

Table 4. Economic feasibility of biogas generation from Al-Russayl WWTP sludge and agri-food wastes co-digestion. Sensitivity study results (Scenario 1: SS alone; Scenario 2: SS+ 2 tonnes day $^{-1}$ of AFW; Scenario 3: SS+ 10 tonnes day ${ }^{-1}$ of AFW; NPV: net present value; IRR: internal return rate; PBP: payback period).

\begin{tabular}{|c|c|c|c|c|}
\hline & & NPV (\$ Million) & IRR (\%) & PBP \\
\hline \multirow{3}{*}{ Baseline option } & Scenario 1 & 0.393 & 19.4 & 7 \\
\hline & Scenario 2 & 0.481 & 20.0 & 7 \\
\hline & Scenario 3 & 0.852 & 21.8 & 6 \\
\hline \multirow{3}{*}{$\begin{array}{l}\text { Option 1: Generated } \\
\text { electricity sold for } \\
\$ 0.148 \mathrm{kWh}^{-1}\end{array}$} & Scenario 1 & 0.569 & 23.6 & 6 \\
\hline & Scenario 2 & 0.688 & 24.3 & 6 \\
\hline & Scenario 3 & 1.181 & 26.5 & 5 \\
\hline \multirow{3}{*}{$\begin{array}{c}\text { Option 2: Total } \\
\text { expenses decrease by } \\
15 \%\end{array}$} & Scenario 1 & 0.706 & 30.1 & 5 \\
\hline & Scenario 2 & 0.845 & 31.0 & 5 \\
\hline & Scenario 3 & 1.419 & 33.9 & 5 \\
\hline \multirow{3}{*}{$\begin{array}{c}\text { Option 3: Total } \\
\text { expenses increase by } \\
15 \%\end{array}$} & Scenario 1 & 0.081 & 11.7 & 9 \\
\hline & Scenario 2 & 0.117 & 12.2 & 9 \\
\hline & Scenario 3 & 0.285 & 13.5 & 9 \\
\hline
\end{tabular}

The best option yielding the highest NPV and IRR corresponds to where the engaged costs were supposed to decrease by $15 \%$ (option 2 ). Under these conditions, the calculated NPV values were determined to be $\$ 0.706, \$ 0.845$, and $\$ 1.419$ million for scenarios 1,2 , 
and 3, respectively. These values are $79.6 \%, 75.6 \%$, and $66.5 \%$ higher than those found for the baseline option. Moreover, the IRR values were significantly higher than the current banking interest rates since they reached $30.1 \%, 31.0 \%$, and $33.9 \%$ for options 1 , 2, and 3 , respectively. The PBP for the three scenarios were evaluated to 5 years only (Figure 6c).

On the other hand, even with a $15 \%$ increase in the calculated costs, the NPV and IRR are still positive and higher than $10 \%$, respectively (Figure 6a,b, and Table 4). However, the related NPV has significantly decreased compared to the baseline option. They were assessed to be about $\$ 80,823, \$ 116,793$, and $\$ 285,047$ for options 1,2 , and 3 , respectively. The IRR values have also considerably decreased compared to the baseline condition, with values of only $11.7 \%, 12.2 \%$, and $13.5 \%$ for options 1,2 , and 3 , respectively. The PBP increased to 9 years for all the studied options (Figure 6c).

It is worth mentioning that the benefits of the digested sludge valorization as organic fertilizers instead of the commercial ones were not included in this study. This is attributed to the uncertainties related to the heavy metals concentrations progress versus time, especially cadmium and molybdenum. In this regard, Alhammad [66], when studying the economic feasibility of turning dairy manure farm (generated by 2000 cows) into electricity at Zarqa, Jordan, reported that the expected revenue from the annual production of organic fertilizer was to $24,000 €$. It is $33 \%$ higher than the benefits derived from electrical energy generation.

On the other hand, it is essential to include in future investigations the social aspect that could include issues related to sludge' odors complaints, the public perception of renewable energy recovery from sludge, and the political support to such technology. Regulatory issues should also be considered in this context. They should emphasize the discrepancies between concerned governmental agencies, tariffs of generated electricity and interconnection with the national grid, and finally, the faced-challenges towards a full-respect of water and sludge discharge/reuse limits as well as air quality.

Finally, for a sustainable environment preservation, the production of sludge should be minimized as maximum as possible at its production source through the promotion of the following major tasks [3]: (i) adopting new processes in the wastewater treatment process, (ii) optimizing the dewatering processes for lower sludge water contents, and (iii) reducing the fraction of volatile solids through various oxidation methods.

\section{Conclusions}

This technical-environmental-economic feasibility shows a substantial potential for biogas and electricity recovery from the digestion of the sludge produced at the Al-Russayl industrial estate WWTP in Oman. Findings were promising when sludge was applied alone or in combination with agri-food wastes, respectively. The best results in terms of biogas production and electricity recovery were obtained in the scenario 3 (sludge mixed with 10 tonnes/day of AFW). In this scenario, significant methane amounts were recovered (more than $18 \mathrm{Mm}^{3}$ ) and converted into electricity (more than $82 \mathrm{GWh}$ ) for the whole project lifetime. This generated electricity is able to cover the overall current needs of the WWTP at this industrial estate. The in situ use of the produced electricity will enhance its energy security and will permit its sustainable functioning. Moreover, the project implementation will significantly reduce the GHG emissions (more than 70,000 $\mathrm{tCO}_{2}$ ) mainly due to the used-generated electricity from biogas instead of the one supplied by the national grid network. The cost-benefit analysis shows that the co-digestion of WWTP sludge with agri-food wastes is particularly economically attractive with maximum NPV and IRR values of $\$ 851,876$ and $21.8 \%$, respectively, and a payback period of six years. The sensitivity analysis demonstrates that the NPV and IRR values reached \$1,418,704 and $34.0 \%$ when the total expenses were reduced by $15 \%$. However, when the total engaged expenses were increased by $15 \%$, the NPV and IRR values considerably decreased, but they were still positive and slightly higher than $10 \%$, respectively.

The in-depth physico-chemical characterization of the sludge and the agri-food wastes produced in the Al-Russayl industrial estate is an essential task for the future updating 
and exploitation of this feasibility study. This characterization will mainly concern mainly their total solid and volatile matter contents, their potential degradability rate, and their calorific energy potential.

The application of such a process in other existing WWTPs and future planned ones will permit Oman to achieve the sustainable goals for low GHG emissions, sanitation, and water resources protection. A thorough assessment of the techno-environment-economic feasibility of biogas production from the co-digestion of sludge and agri-food wastes in the planned WWTP will enable the government to implement new sustainable and environmental-friendly plants. These plants should integrate the biogas recovery and conversion into electricity and the agronomic valorization of the generated digestate, which are essential steps towards circular economy concept application and sustainability.

Author Contributions: Conceptualization, S.J. and Y.C.; methodology, S.J., M.U., and Y.C.; validation, A.A.-B., and M.J.; formal analysis, S.J. and Y.C.; investigation, S.J., M.J., and Y.C.; data curation, Y.C. and M.J.; writing—original draft preparation, S.J; writing—review and editing, Y.C., M.U., A.A.-B., and M.J; supervision, Y.C. and A.A.-B.; project administration, S.J.; funding acquisition, S.J., Y.C. and A.A.-B. All authors have read and agreed to the published version of the manuscript.

Funding: Madayn is gratefully acknowledged for the funding of this research work in the framework of the project number: Chair/DVC/Madayn/20/01.

Institutional Review Board Statement: Not applicable.

Informed Consent Statement: Not applicable.

Data Availability Statement: Data available on request.

Acknowledgments: Authors would like to thank Lokman Zaibet for his technical and scientific support.

Conflicts of Interest: The authors declare no conflict of interest.

\section{References}

1. Gherghel, A.; Teodosiu, C.; De Gisi, S. A review on wastewater sludge valorisation and its challenges in the context of circular economy. J. Clean. Prod. 2019, 228, 244-263. [CrossRef]

2. Fijalkowski, K.; Rorat, A.; Grobelak, A.; Kacprzak, M.J. The presence of contaminations in sewage sludge-The current situation. J. Environ. Manag. 2017, 203, 1126-1136. [CrossRef]

3. Collivignarelli, M.C.; Abbà, A.; Miino, M.C.; Torretta, V. What Advanced Treatments Can Be Used to Minimize the Production of Sewage Sludge in WWTPs? Appl. Sci. 2019, 9, 2650. [CrossRef]

4. European Commission. Environmental, Economic and Social Impacts of the Use of Sewage Sludge on Land. Consultant Report Options Impacts; Report by RPA, Milieu Ltd., WRc and European Commission, DG Environment under Study Contract DG ENV.G.4/ETU/2008/0076r; European Commission: Brussels, Belgium, 2009.

5. Seleiman, M.F.; Santanen, A.; Mäkelä, P.S.A. Recycling sludge on cropland as fertilizer-Advantages and risks. Resour. Conserv. Recycl. 2020, 155, 104647. [CrossRef]

6. Chang, Z.; Long, G.; Zhou, J.L.; Ma, C. Valorization of sewage sludge in the fabrication of construction and building materials: A review. Resour. Conserv. Recycl. 2020, 154, 104606. [CrossRef]

7. Raheem, A.; Sikarwar, V.S.; He, J.; Dastyar, W.; Dionysiou, D.D.; Wang, W.; Zhao, M. Opportunities and challenges in sustainable treatment and resource reuse of sewage sludge: A review. Chem. Eng. J. 2018, 337, 616-641. [CrossRef]

8. Kor-Bicakci, G.; Eskicioglu, C. Recent developments on thermal municipal sludge pretreatment technologies for enhanced anaerobic digestion. Renew. Sustain. Energy Rev. 2019, 110, 423-443. [CrossRef]

9. Cao, Y.; Pawłowski, A. Sewage sludge-to-energy approaches based on anaerobic digestion and pyrolysis: Brief overview and energy efficiency assessment. Renew. Sustain. Energy Rev. 2012, 16, 1657-1665. [CrossRef]

10. Oladejo, J.; Shi, K.; Luo, X.; Yang, G.; Wu, T. A Review of Sludge-to-Energy Recovery Methods. Energies 2019, 12, 60. [CrossRef]

11. Lee, I.S.; Parameswaran, P.; Rittmann, B.E. Effects of solids retention time on methanogenesis in anaerobic digestion of thickened mixed sludge. Bioresour. Technol. 2011, 102, 10266-10272. [CrossRef] [PubMed]

12. Aryal, N.; Kvist, T. Alternative of Biogas Injection into the Danish Gas Grid System-A Study from Demand Perspective. ChemEngineering 2018, 2, 43. [CrossRef]

13. Mills, N.; Pearce, P.; Farrow, J.; Thorpe, R.B.; Kirkby, N.F. Environmental \& economic life cycle assessment of current \& future sewage sludge to energy technologies. Waste Manag. 2014, 34, 185-195. [CrossRef]

14. Shen, Y.; Linville, J.L.; Urgun-Demirtas, M.; Mintz, M.M.; Snyder, S.W. An overview of biogas production and utilization at full-scale wastewater treatment plants (WWTPs) in the United States: Challenges and opportunities towards energy-neutral WWTPs. Renew. Sustain. Energy Rev. 2015, 50, 346-362. [CrossRef] 
15. Wei, L.; Zhu, F.; Li, Q.; Xue, C.; Xia, X.; Yu, H.; Zhao, Q.; Jiang, J.; Bai, S. Development, current state and future trends of sludge management in China: Based on exploratory data and CO2-equivaient emissions analysis. Environ. Int. 2020, $144,106093$. [CrossRef]

16. Scarlat, N.; Dallemand, J.F.; Fahl, F. Biogas: Developments and perspectives in Europe. Renew. Energy 2018, 129, 457-472. [CrossRef]

17. Werle, S.; Wilk, R.K. A review of methods for the thermal utilization of sewage sludge: The Polish perspective. Renew. Energy 2010, 35, 1914-1919. [CrossRef]

18. EurObserv'ER Biogas Barometer. EurObserv'ER, 2020. Available online: https://www.eurobserv-er.org/biogas-barometer-2020/ (accessed on 15 March 2021).

19. Torres-León, C.; Ramírez-Guzman, N.; Londoño-Hernandez, L.; Martinez-Medina, G.A.; Díaz-Herrera, R.; Navarro-Macias, V.; Alvarez-Pérez, O.B.; Picazo, B.; Villarreal-Vázquez, M.; Ascacio-Valdes, J.; et al. Food Waste and Byproducts: An Opportunity to Minimize Malnutrition and Hunger in Developing Countries. Front. Sustain. Food Syst. 2018, 2, 52. [CrossRef]

20. Czekała, W. Agricultural Biogas Plants as a Chance for the Development of the Agri-Food Sector. J. Ecol. Eng. 2018, 19, 179-183. [CrossRef]

21. Król, K.; Iskra, K.; Ferens, W.; Miodoński, J.M. Testing properties of sewage sludge for energy use. Environ. Prot. Eng. 2019, 45, epe190405. [CrossRef]

22. Ahmad, N.; Sahrin, N.; Talib, N.; Abdul Ghani, F. Characterization of energy content in food waste by using thermogravimetric analyser (TGA) and elemental analyser (CHNS-O). J. Phys. Conf. Ser. 2019, 1349, 012140. [CrossRef]

23. Zhang, C.; Su, H.; Baeyens, J.; Tan, T. Reviewing the anaerobic digestion of food waste for biogas production. Renew. Sustain. Energy Rev. 2014, 38, 383-392. [CrossRef]

24. Kuo, J.; Dow, J. Biogas production from anaerobic digestion of food waste and relevant air quality implications. J. Air Waste Manag. Assoc. 2017, 67, 1000-1011. [CrossRef] [PubMed]

25. Bertanza, G.; Canato, M.; Laera, G. Towards energy self-sufficiency and integral material recovery in waste water treatment plants: Assessment of upgrading options. J. Clean. Prod. 2018, 170, 1206-1218. [CrossRef]

26. Keucken, A.; Habagil, M.; Batstone, D.; Jeppsson, U.; Arnell, M. Anaerobic Co-Digestion of Sludge and Organic Food WastePerformance, Inhibition, and Impact on the Microbial Community. Energies 2018, 11, 2325. [CrossRef]

27. Guimarães, C.D.S.; Maia, D.R.D.S.; Serra, E.G. Construction of Biodigesters to Optimize the Production of Biogas from Anaerobic Co-Digestion of Food Waste and Sewage. Energies 2018, 11, 870. [CrossRef]

28. Morales-Polo, C.; del Mar Cledera-Castro, M.; Soria, B.Y.M. Reviewing the Anaerobic Digestion of Food Waste: From Waste Generation and Anaerobic Process to Its Perspectives. Appl. Sci. 2018, 8, 1804. [CrossRef]

29. Mohammed, M.; Egyir, I.S.; Donkor, A.K.; Amoah, P.; Nyarko, S.; Boateng, K.K.; Ziwu, C. Feasibility study for biogas integration into waste treatment plants in Ghana. Egypt. J. Pet. 2017, 26, 695-703. [CrossRef]

30. Khadhar, S.; Sdiri, A.; Chekirben, A.; Azouzi, R.; Charef, A. Integration of sequential extraction, chemical analysis and statistical tools for the availability risk assessment of heavy metals in sludge amended soils. Environ. Pollut. 2020, 263, 114543. [CrossRef]

31. Chow, W.L.; Chong, S.; Lim, J.W.; Chan, Y.J.; Chong, M.F.; Tiong, T.J.; Chin, J.K.; Pan, G.T. Anaerobic Co-Digestion of Wastewater Sludge: A Review of Potential Co-Substrates and Operating Factors for Improved Methane Yield. Processes 2020, 8, 39. [CrossRef]

32. Islam, M.N.; Park, K.-J.; Yoon, H.-S. Methane Production Potential of Food Waste and Food Waste Mixture with Swine Manure in Anaerobic Digestion. J. Biosyst. Eng. 2012, 37, 100-105. [CrossRef]

33. Zhang, C.; Su, H.; Tan, T. Batch and semi-continuous anaerobic digestion of food waste in a dual solid-liquid system. Bioresour. Technol. 2013, 145, 10-16. [CrossRef] [PubMed]

34. Akbulut, A. Techno-economic analysis of electricity and heat generation from farm-scale biogas plant: Çiçekdağ1 case study. Energy 2012, 44, 381-390. [CrossRef]

35. Charabi, Y.; Al-Awadhi, T.; Choudri, B.S. Strategic pathways and regulatory choices for effective GHG reduction in hydrocarbon based economy: Case of Oman. Energy Rep. 2018, 4, 653-659. [CrossRef]

36. Hamrick, K.; Gallant, M. State of the Voluntary Carbon Markets 2017; International Water Power \& Dam Construction: London, UK, 2017.

37. Bidart, C.; Fröhling, M.; Schultmann, F. Electricity and substitute natural gas generation from the conversion of wastewater treatment plant sludge. Appl. Energy 2014, 113, 404-413. [CrossRef]

38. Morin, P.; Marcos, B.; Moresoli, C.; Laflamme, C.B. Economic and environmental assessment on the energetic valorization of organic material for a municipality in Quebec, Canada. Appl. Energy 2010, 87, 275-283. [CrossRef]

39. Martin, J.H.; Oemler, J.A. A Protocol for Quantifying and Reporting the Performance of Anaerobic Digestion Systems for Livestock Manures. In Proceedings of the International Symposium on Air Quality and Waste Management for Agriculture, Broomfield, CO, USA, 16-19 September 2007.

40. European Environment Agency. EEA Greenhouse Gas-Data Viewer. Data Viewer Greenhouse Gas Emissions and Removals, Sent by Countries to UNFCCC EU Greenhouse Gas Monitoring Mechanism (EU Member States); European Environment Agency: Copenhagen, Denmark, 2019.

41. Adani, F.; Tambone, F. Long-term effect of sewage sludge application on soil humic acids. Chemosphere 2005, 60, 1214-1221. [CrossRef] [PubMed] 
42. Zhang, J.; Sugir, M.E.; Li, Y.; Yuan, L.; Zhou, M.; Lv, P.; Yu, Z.; Wang, L.; Zhou, D. Effects of vermicomposting on the main chemical properties and bioavailability of $\mathrm{Cd} / \mathrm{Zn}$ in pure sludge. Environ. Sci. Pollut. Res. 2019, 26, 20949-20960. [CrossRef] [PubMed]

43. Janowska, B.; Szymański, K.; Sidełko, R.; Siebielska, I.; Walendzik, B. Assessment of mobility and bioavailability of mercury compounds in sewage sludge and composts. Environ. Res. 2017, 156, 394-403. [CrossRef]

44. Collivignarelli, M.C.; Abbà, A.; Frattarola, A.; Miino, M.C.; Padovani, S.; Katsoyiannis, I.; Torretta, V. Legislation for the Reuse of Biosolids on Agricultural Land in Europe: Overview. Sustainability 2019, 11, 6015. [CrossRef]

45. Verbinnen, B.; Block, C.; Hannes, D.; Lievens, P.; Vaclavikova, M.; Stefusova, K.; Gallios, G.; Vandecasteele, C. Removal of Molybdate Anions from Water by Adsorption on Zeolite-Supported Magnetite. Water Environ. Res. 2012, 84, 753-760. [CrossRef] [PubMed]

46. Zhu, H.; Huang, Q.; Fu, S.; Zhang, X.; Shi, M.; Liu, B. Removal of Molybdenum(VI) from Raw Water Using Nano Zero-Valent Iron Supported on Activated Carbon. Water 2020, 12, 3162. [CrossRef]

47. Council of European Communities. Council Directive 86/278/EEC of 12 June 1986 on the protection of the environment, and in particular of the soil, when sewage sludge is used in agriculture. Off. J. Eur. Communities 1986, 86, 278.

48. Baawain, M.S.; Al-Jabri, M.; Choudri, B.S. Characterization of Industrial Wastewater Sludge in Oman from Three Different Regions and Recommendations for Alternate Reuse Applications. Iran. J. Public Health 2015, 44, 1473-1481.

49. Alrawashdeh, K.A.B.; Gul, E.; Yang, Q.; Yang, H.; Bartocci, P.; Fantozzi, F. Effect of Heavy Metals in the Performance of Anaerobic Digestion of Olive Mill Waste. Processes 2020, 8, 1146. [CrossRef]

50. Abdel-Shafy, H.I.; Mansour, M.S.M. Biogas production as affected by heavy metals in the anaerobic digestion of sludge. Egypt. J. Pet. 2014, 23, 409-417. [CrossRef]

51. Appels, L.; Baeyens, J.; Degrève, J.; Dewil, R. Principles and potential of the anaerobic digestion of waste-activated sludge. Prog. Energy Combust. Sci. 2008, 34, 755-781. [CrossRef]

52. Berktay, A.; Nas, B. Biogas Production and Utilization Potential of Wastewater Treatment Sludge. Energy Sources Part A Recover. Util. Environ. Eff. 2008, 30, 179-188. [CrossRef]

53. Gurieff, N.; Bruus, J.; Nielsen, B.; Nawawi-Lansade, D.; Cantegril, M. Moving towards an energy neutral WWTP-The positive impact of ExelysTM continuous thermal hydrolysis in achieving this goal. Water Pr. Technol. 2012, 7, 1-8. [CrossRef]

54. Tarallo, S. Demonstrated Energy Neutrality Leadership: A Study of Five Champions of Change. Water Intell. Online 2015, 14. [CrossRef]

55. Bachmann, N. Sustainable Biogas Production in Municipal Wastewater Treatment Plants; IEA Bioenergy: Massongex, Switzerland, 2015.

56. Mattioli, A.; Gatti, G.B.; Mattuzzi, G.P.; Cecchi, F.; Bolzonella, D. Co-digestion of the organic fraction of municipal solid waste and sludge improves the energy balance of wastewater treatment plants: Rovereto case study. Renew. Energy 2017, 113, 980-988. [CrossRef]

57. Koch, K.; Plabst, M.; Schmidt, A.; Helmreich, B.; Drewes, J.E. Co-digestion of food waste in a municipal wastewater treatment plant: Comparison of batch tests and full-scale experiences. Waste Manag. 2016, 47, 28-33. [CrossRef] [PubMed]

58. Maktabifard, M.; Zaborowska, E.; Makinia, J. Achieving energy neutrality in wastewater treatment plants through energy savings and enhancing renewable energy production. Rev. Environ. Sci. Biotechnol. 2018, 17, 655-689. [CrossRef]

59. Koch, K.; Helmreich, B.; Drewes, J.E. Co-digestion of food waste in municipal wastewater treatment plants: Effect of different mixtures on methane yield and hydrolysis rate constant. Appl. Energy 2015, 137, 250-255. [CrossRef]

60. Eggleston, H.S.; Buendia, L.; Miwa, K.; Ngara, T.; Tanabe, K. Energy. In IPCC Guidelines for National Greenhouse Gas Inventories; IPCC: Geneva, Switzerland, 2006; Volume 2.

61. Parravicini, V.; Svardal, K.; Krampe, J. Greenhouse Gas Emissions from Wastewater Treatment Plants. Energy Procedia 2016, 97, 246-253. [CrossRef]

62. Chai, C.; Zhang, D.; Yu, Y.; Feng, Y.; Wong, M.S. Carbon Footprint Analyses of Mainstream Wastewater Treatment Technologies under Different Sludge Treatment Scenarios in China. Water 2015, 7, 918-938. [CrossRef]

63. Law, Y.; Ye, L.; Pan, Y.; Yuan, Z. Nitrous oxide emissions from wastewater treatment processes. Philos. Trans. R. Soc. B Biol. Sci. 2012, 367, 1265-1277. [CrossRef]

64. Yoshida, H.; Mønster, J.; Scheutz, C. Plant-integrated measurement of greenhouse gas emissions from a municipal wastewater treatment plant. Water Res. 2014, 61, 108-118. [CrossRef] [PubMed]

65. Edwards, J.; Othman, M.; Burn, S. A review of policy drivers and barriers for the use of anaerobic digestion in Europe, the United States and Australia. Renew. Sustain. Energy Rev. 2015, 52, 815-828. [CrossRef]

66. Alhammad, Z. Feasibility Study for a Biogas Plant in Jordan. J. Energy Res. Rev. 2019, 1-6. [CrossRef] 